\title{
Local Protein Synthesis and Spine Morphogenesis: Fragile X Syndrome and Beyond
}

\author{
Aaron W. Grossman, ${ }^{1,2,3 *}$ Georgina M. Aldridge, ${ }^{1,2,3 *}$ Ivan Jeanne Weiler, ${ }^{1}$ and William T. Greenough ${ }^{1,2,4}$ \\ ${ }^{1}$ Beckman Institute, ${ }^{2}$ Neuroscience Graduate Program, ${ }^{3}$ Medical Scholars Program, and ${ }^{4}$ Departments of Psychology, Psychiatry, and Cell and Structural \\ Biology, University of Illinois at Urbana-Champaign, Urbana, Illinois 61801
}

\begin{abstract}
Behavioral experiences can modulate neural networks through changes in synaptic morphology and number. In contrast, abnormal morphogenesis of dendritic spines is associated with cognitive impairment, as in Fragile X syndrome. Dendritic or synaptic protein synthesis could provide the specificity and speed necessary for spine morphogenesis. Here, we highlight locally translated proteins shown to affect synaptic morphology (e.g., Fragile X mental retardation protein).
\end{abstract}

Key words: synaptic plasticity, CaMKII; FMRP; Rho GTPases; Fmr1 knock-out mice; synaptogenesis; learning and memory; metabotropic glutamate receptor; Rac1; SHANK-HOMER; dendritic spine; PSD-95

Behavioral experiences can modulate the function of individual synapses or entire neural networks through changes in synaptic morphology and number (Bailey and Chen, 1983; Black et al., 1990). Recent in vivo imaging studies have shown that experience or activity can induce morphogenesis (or changes in shape or motility) of postsynaptic spines, sites for excitatory synapses (Majewska and Sur, 2003; Zuo et al., 2005). Abnormal spine morphogenesis, in contrast, is associated with cognitive impairment, as in Fragile X syndrome (FXS) and other disorders (Purpura, 1974; Hinton et al., 1991). Reactive spine morphogenesis likely requires rapid availability of macromolecules, and dendritic or synaptic protein synthesis could provide specificity and speed. Although direct evidence tying local protein synthesis to spine morphogenesis is scarce, we review the available indirect evidence with an emphasis on locally translated proteins, including the Fragile $\mathrm{X}$ mental retardation protein (FMRP), that have known effects on synaptic morphology.

Markers of translation [polyribosomal aggregates (PRAs)] have been observed near synapses during peak developmental synaptogenesis (Steward and Falk, 1986), and local protein synthesis is regulated by intrinsic and extrinsic signals (Schuman et al., 2006). Greenough et al. (1985) found that PRAs were localized to dendritic spines in the visual cortex of rats exposed to a complex environment, a paradigm that alters the number, shape, and size of synapses (Grossman et al., 2002). Induction of longterm potentiation (LTP), an electrically induced change in synaptic strength, also moves PRAs from dendritic shafts into spines

Received April 27, 2006; revised May 27, 2006; accepted May 28, 2006.

This work was supported by National Institutes of Health Grants MH35321, AG10154, and HD07333, by the FRAXA Foundation, and by the Spastic Paralysis and Allied Diseases of the Central Nervous System Research Foundation. We gratefully acknowledge Kathy Bates and Julie Markham for their contributions to this work.

${ }^{*}$ A.W.G. and G.M.A. contributed equally to this work.

Correspondence should be addressed to Dr. William T. Greenough, Beckman Institute, University of Illinois at Urbana-Champaign, 405 North Mathews, Urbana, IL 61801. E-mail: wgreenou@uiuc.edu.

DOI:10.1523/JNEUROSCI.1790-06.2006

Copyright $\odot 2006$ Society for Neuroscience $\quad$ 0270-6474/06/267151-05\$15.00/0
(Ostroff et al., 2002). Furthermore, only spine synapses that contained PRAs were larger after stimulation, suggesting that local translation was important for this morphogenesis.

Another model of synaptic activation involves administration of neurotransmitter receptor agonists. Weiler et al. (1997) used synaptoneurosomes (synapses dissociated from cell bodies) to show that stimulation of metabotropic glutamate receptors (mGluRs) triggers rapid aggregation of polyribosomes and translation of proteins (including FMRP). Vanderklish and Edelman (2002) recently reported elongation of dendritic spines after stimulation of mGluRs. Preincubation with a translation inhibitor blocked elongation, but it remains unclear whether the protein synthesis required is specifically dendritic.

Translation inhibitors have been used for many years to establish the importance of protein synthesis for memory, synaptic morphogenesis, and cortical function (Agranoff and Klinger, 1964; Kleim et al., 2003). Failure to synthesize specific proteins can profoundly affect synapse morphology. For example, patients with FXS (characterized by the absence of FMRP) exhibit elevated spine density in the neocortex as adults and an abundance of spines with morphologies commonly observed early in development (Hinton et al., 1991; Irwin et al., 2001). This phenotype is also seen in the neocortex and hippocampus of adult mice lacking FMRP (Fmr1 knock-out mice), suggesting a deficit in synaptic maturation (Galvez and Greenough, 2005; Grossman et al., 2006).

One emphasis of recent research has been to differentiate possible roles of local from somatic protein synthesis in specific forms of synaptic plasticity (Pfeiffer and Huber, 2006). Studies using isolated dendrites have demonstrated that local translation is both necessary and sufficient for establishment and maintenance of LTP (Cracco et al., 2005; Vickers et al., 2005). Similarly, Schuman and colleagues (Kang and Schuman, 1996; Aakalu et al., 2001) demonstrated that local protein synthesis is important for synaptic potentiation after administration of the neurotrophin BDNF and, more recently, have visualized dynamics of local 
translation associated with synaptic potentiation. In the future, these techniques and others in which protein synthesis is restricted to the soma of intact neurons (Miller et al., 2002; Bradshaw et al., 2003) can delineate the necessity for local protein synthesis in spine morphogenesis.

\section{Locally translated proteins important for spine morphology}

Specific proteins and biochemical pathways have been associated with spine morphogenesis (Tada and Sheng, 2006); many of these pathways lead ultimately to actin rearrangement in the spine cytoskeleton. Rho GTPases such as Rac1, for example, are upstream modulators of actin polymerization. Their activity is regulated by environmental signals such as visual input, and stimulation of these Rho GTPase pathways affects spine morphology and stability (Sin et al., 2002; Tashiro and Yuste, 2004). Proteins that are important for spine formation and remodeling and that are locally translated can be grouped into two broad functional categories: (1) direct or indirect "regulators" of spine formation and remodeling and (2) "plastic structural elements" that integrate structurally into the synapse, thus influencing synaptic physiology and potentially altering the capacity for future morphogenesis. Although evidence directly linking local synthesis of specific proteins to spine changes is sparse, proteins from both of these categories are linked to pathways that can affect spine morphogenesis (Fig. 1).

\section{Regulators}

Many locally synthesized proteins can potentially influence other proteins or signaling cascades involved in morphogenesis. For example, local translation of kinases or phosphatases could rapidly shift the equilibrium among pathways operating within the spine. Synthesis of RNA-binding proteins would have longerterm effects (Wells, 2006).

FMRP. The Fmrl mRNA is found in neuronal somata, dendrites, and spines. Activation of mGluRs localizes Fmr1 to dendrites and initiates translation of FMRP in synaptoneurosomes (Weiler et al., 1997; Antar et al., 2004). Activity-induced translation of FMRP could affect spine morphology via interactions with its protein binding partners, including cytoplasmic FMRP interacting protein 1 (CYFIP1) (Schenck et al., 2003). In Drosophila, CYFIP and FMRP may regulate Rac1, and in mice, FMRP may also regulate other members of this actin-polymerization cascade (Kobayashi et al., 1998; Castets et al., 2005). Inhibition of Racl results in longer spines and decreased spine head size, as well as reduced head morphing and reduced spine stability (Tashiro and Yuste, 2004).

In addition to being synthesized at synapses, FMRP binds mRNA and ribosomes and seems to regulate mRNA transport and synaptic protein synthesis (Weiler et al., 1997; Khandjian et al., 2004). Weiler et al. (2004) found that stimulating mGluRs in synaptoneurosomes rapidly initiated translation in wild-type but not Fmr1 knock-out mice, indicating that FMRP is important for neurotransmitter-activated protein synthesis. FMRP could affect spine morphogenesis through regulation of "cargo" mRNA, such as Map1B mRNA, shown recently to colocalize with FMRP near synapses (Antar et al., 2005). Map1B binds both actin and microtubules, and microtubule stability seems to be increased in Fmr1 knock-out mice (Lu et al., 2004). Whereas these observations indicate that FMRP is important for initiating translation at synapses, FMRP may also inhibit constitutive protein synthesis elsewhere in the cell (Laggerbauer et al., 2001; Li et al., 2001). Together, these findings support a dual role for FMRP: delivery of protected mRNAs to synaptic locations and release of mRNAs for activity-dependent translation (Davidovic et al., 2005; Weiler, 2005).

Thus, at least three mechanisms may contribute to the abnormal spine morphology in FXS: (1) loss of protein-protein interactions leading to disruption of morphogenesis pathways; (2) dysregulated local synthesis of proteins important for morphogenesis; and (3) mislocalization of mRNA cargoes, any number of which could be critical for spine morphogenesis. These cargoes include $\mathrm{Ca}^{2+} /$ calmodulin-dependent protein kinase II (CaMKII) (discussed below), calbindin, the $\alpha$-glucocorticoid receptor, and cadherins (for more complete lists, see Sung et al., 2000; Brown et al., 2001; Miyashiro et al., 2003). Abnormal transport and translation of FMRP cargoes may underlie many other symptoms of FXS, as well (Markham et al., 2006).

CaMKII. CaMKII makes up a substantial proportion of the postsynaptic density (PSD) and may function both as a regula- 
tory kinase and a scaffolding molecule for recruiting synaptic proteins (Merrill et al., 2005). Local protein synthesis appears to play a significant role in the regulation of dendritic CaMKII; its mRNA is observed throughout apical dendrites of hippocampal neurons, and mice missing dendritic targeting regions of $\alpha$-CaMKII mRNA have reduced levels of the protein in their PSDs (Martone et al., 1996; Miller et al., 2002). The dynamics of local CaMKII translation remain unclear but may involve association of FMRP with CaMKII mRNA through the small RNA BC1 (Zalfa et al., 2003). Introducing phosphorylated CaMKII causes immediate formation of long, thin filopodia and shorter dendritic spines; in contrast, preventing CaMKII phosphorylation inhibits morphological changes that follow LTP induction (Jourdain et al., 2003). In mice in which CaMKII is restricted from dendrites, late-phase LTP and spatial memory are impaired, as are associative fear conditioning and object-recognition memory (Miller et al., 2002).

The proposed roles of CaMKII in spine morphogenesis are threefold. (1) It phosphorylates signaling proteins, potentially activating or repressing morphogenesis pathways. For example, CaMKII phosphorylates SynGAP (synaptic GTPase-activating protein), a regulator of the RAS-Rac1 actin-polymerization pathway (Song et al., 2004). (2) CaMKII acts as a regulator of protein translation through activation of cytoplasmic polyadenylation element-binding protein (CPEB) (Atkins et al., 2004) and could therefore, like FMRP, wield influence on morphogenesis through mRNA targets. (3) CaMKII may act as a plastic structural element by accumulating at the PSD in response to neuronal stimulation (Otmakhov et al., 2004), and by binding nearby synaptic proteins. For example, the NR2B subunit of NMDA receptors, which are important for spine morphogenesis, may be recruited to synapses by CaMKII (Zhou et al., 2004; Robison et al., 2005). Additional studies restricting CaMKII to the somata (Miller et al., 2002) should examine spine morphology to determine whether local synthesis of CaMKII is required for normal morphogenesis.

\section{Plastic structural elements}

Local synthesis of synaptic structural elements used by rapidly developing or remodeling spines can replenish pools of raw material. They may also provide a substrate for future morphological change, or plasticity. For example, mRNA for the cytoskeletal protein $\beta$-actin is localized to dendrites in an activity-dependent manner (Tiruchinapalli et al., 2003). Upregulation of $\beta$-actin mRNA stimulates the formation of dendritic filopodia, whereas exclusion of $\beta$-actin mRNA from dendrites disrupts the production of filopodia (Eom et al., 2003). Activity-induced remodeling of actin filaments provides a dynamic scaffold for localization of additional kinases and receptors (Ouyang et al., 2005), potentially affecting postsynaptic responses and the capacity of the spine to exhibit future morphogenesis. The concept of plastic structural elements is consistent with the idea of "metaplasticity" and may enable "synapses to integrate a response across temporally spaced episodes of synaptic activity" (Abraham and Tate, 1997).

PSD-95. PSD-95 is a locally synthesized scaffolding molecule, the expression levels of which increase after stimulation of mGluRs (Todd et al., 2003; Lee et al., 2005). Overexpression of PSD-95 in cultured hippocampal neurons leads to synapse maturation, clustering of glutamate receptors, and increased spine density and size (El-Husseini et al., 2000). PSD-95 can also bind and recruit to the PSD essential synaptic components, many of which independently affect spine shape (e.g., NMDA receptors, Homer, and others) (Kim and Sheng, 2004). Furthermore,
PSD-95 binds and targets to synapses kalirin-7, a regulator of Racl signaling and spine morphogenesis (Penzes et al., 2001). Finally, the mGluR-induced increase in PSD-95 appears to require FMRP (Todd et al., 2003), suggesting that in FXS, deficits in local translation of PSD-95 may lead to abnormal spine morphogenesis and may affect spine responsiveness to future signals.

SHANK and Homer. SHANKs are scaffolding elements that bind indirectly to PSD-95 and F-actin (Boeckers et al., 2002). The mRNAs for SHANK1 and SHANK3 are localized to dendrites, and SHANK has dramatic effects on spine morphogenesis, inducing development of spines on non-spiny neurons (Bockers et al., 2004; Roussignol et al., 2005). It interacts with actinassociated proteins such as cortactin and appears to assemble NMDA receptors and mGluRs at spines (Boeckers et al., 2002). SHANK may exert some of its synaptic effects by binding the locally synthesized adapter protein Homer2 and together recruiting synaptic components such as $\mathrm{IP}_{3}$ receptors, PSD-95, and F-actin to the spine (Sala et al., 2001; Schratt et al., 2004). Homer can cluster mGluRs at plasma membranes and can interact with Rho GTPase pathways (Shiraishi et al., 1999; Kammermeier, 2006), thus potentially affecting postsynaptic responses to neurotransmitter signals. Together, the SHANK-Homer2 complex increases the density of mushroom and multi-synapse spines (Sala et al., 2001). In mice lacking FMRP, phosphorylation of Homer protein is impaired, as is its association with mGluRs; lower levels of PSD-associated mGluRs in Fmr1 knock-out mice suggest that Homer dysregulation contributes to the spine phenotype of FXS (Giuffrida et al., 2005).

These examples of regulators and plastic structural elements represent some of the locally synthesized proteins that influence spine morphogenesis. As new candidates appear [e.g., AMPA receptor subunit GluR1 (Smith et al., 2005) and $\beta$-thymosin (van Kesteren et al., 2006)], our understanding of the dynamics between local protein synthesis and spine morphogenesis will continue to develop.

\section{References}

Aakalu G, Smith WB, Nguyen N, Jiang C, Schuman EM (2001) Dynamic visualization of local protein synthesis in hippocampal neurons. Neuron 30:489-502.

Abraham WC, Tate WP (1997) Metaplasticity: a new vista across the field of synaptic plasticity. Prog Neurobiol 52:303-323.

Agranoff BW, Klinger PD (1964) Puromycin effect on memory fixation in the goldfish. Science 146:952-953.

Antar LN, Afroz R, Dictenberg JB, Carroll RC, Bassell GJ (2004) Metabotropic glutamate receptor activation regulates Fragile $\mathrm{X}$ mental retardation protein and FMR1 mRNA localization differentially in dendrites and at synapses. J Neurosci 24:2648-2655.

Antar LN, Dictenberg JB, Plociniak M, Afroz R, Bassell GJ (2005) Localization of FMRP-associated mRNA granules and requirement of microtubules for activity-dependent trafficking in hippocampal neurons. Genes Brain Behav 4:350-359.

Atkins CM, Nozaki N, Shigeri Y, Soderling TR (2004) Cytoplasmic polyadenylation element binding protein-dependent protein synthesis is regulated by calcium/calmodulin-dependent protein kinase II. J Neurosci 24:5193-5201.

Bailey CH, Chen M (1983) Morphological basis of long-term habituation and sensitization in Aplysia. Science 220:91-93.

Black JE, Isaacs KR, Anderson BJ, Alcantara AA, Greenough WT (1990) Learning causes synaptogenesis, whereas motor activity causes angiogenesis, in cerebellar cortex of adult rats. Proc Natl Acad Sci USA 87:5568-5572.

Bockers TM, Segger-Junius M, Iglauer P, Bockmann J, Gundelfinger ED, Kreutz MR, Richter D, Kindler S, Kreienkamp HJ (2004) Differential expression and dendritic transcript localization of Shank family members: identification of a dendritic targeting element in the $3^{\prime}$ untranslated region of Shank1 mRNA. Mol Cell Neurosci 26:182-190. 
Boeckers TM, Bockmann J, Kreutz MR, Gundelfinger ED (2002) ProSAP/ Shank proteins-a family of higher order organizing molecules of the postsynaptic density with an emerging role in human neurological disease. J Neurochem 81:903-910.

Bradshaw KD, Emptage NJ, Bliss TV (2003) A role for dendritic protein synthesis in hippocampal late LTP. Eur J Neurosci 18:3150-3152.

Brown V, Jin P, Ceman S, Darnell JC, O’Donnell WT, Tenenbaum SA, Jin X, Feng Y, Wilkinson KD, Keene JD, Darnell RB, Warren ST (2001) Microarray identification of FMRP-associated brain mRNAs and altered mRNA translational profiles in fragile X syndrome. Cell 107:477-487.

Castets M, Schaeffer C, Bechara E, Schenck A, Khandjian EW, Luche S, Moine H, Rabilloud T, Mandel JL, Bardoni B (2005) FMRP interferes with the Racl pathway and controls actin cytoskeleton dynamics in murine fibroblasts. Hum Mol Genet 14:835-844.

Cracco JB, Serrano P, Moskowitz SI, Bergold PJ, Sacktor TC (2005) Protein synthesis-dependent LTP in isolated dendrites of CA1 pyramidal cells. Hippocampus 15:551-556.

Davidovic L, Tremblay S, DeKonink P, Khandjian EW (2005) Fragile X mental retardation protein: to be or not to be a translational repressor. In: The molecular basis of Fragile X syndrome (Denman RB, Sung YJ, eds), pp 201-215. Kerala, India: Research Signpost.

El-Husseini AE, Schnell E, Chetkovich DM, Nicoll RA, Bredt DS (2000) PSD-95 involvement in maturation of excitatory synapses. Science 290:1364-1368.

Eom T, Antar LN, Singer RH, Bassell GJ (2003) Localization of a beta-actin messenger ribonucleoprotein complex with zipcode-binding protein modulates the density of dendritic filopodia and filopodial synapses. J Neurosci 23:10433-10444.

Galvez R, Greenough WT (2005) Sequence of abnormal dendritic spine development in primary somatosensory cortex of a mouse model of the fragile X mental retardation syndrome. Am J Med Genet A 135:155-160.

Giuffrida R, Musumeci S, D’Antoni S, Bonaccorso CM, Giuffrida-Stella AM, Oostra BA, Catania MV (2005) A reduced number of metabotropic glutamate subtype 5 receptors are associated with constitutive homer proteins in a mouse model of Fragile X syndrome. J Neurosci 25:8908-8916.

Greenough WT, Hwang HM, Gorman C (1985) Evidence for active synapse formation or altered postsynaptic metabolism in visual cortex of rats reared in complex environments. Proc Natl Acad Sci USA 82:4549-4552.

Grossman AW, Churchill JD, Bates KE, Kleim JA, Greenough WT (2002) A brain adaptation view of plasticity: is synaptic plasticity an overly limited concept? Prog Brain Res 138:91-108.

Grossman AW, Elissou NM, McKinney BC, Greenough WT (2006) Hippocampal pyramidal cells in adult Fmrl knockout mice exhibit an immature-appearing profile of dendritic spines. Brain Res 1084:160-166.

Hinton VJ, Brown WT, Wisniewski K, Rudelli RD (1991) Analysis of neocortex in three males with the Fragile X syndrome. Am J Med Genet 41:289-294.

Irwin SA, Patel B, Idupulapati M, Harris JB, Crisostomo RA, Larsen BP, Kooy F, Willems PJ, Cras P, Kozlowski PB, Swain RA, Weiler IJ, Greenough WT (2001) Abnormal dendritic spine characteristics in the temporal and visual cortices of patients with Fragile-X syndrome: a quantitative examination. Am J Med Genet 98:161-167.

Jourdain P, Fukunaga K, Muller D (2003) Calcium/calmodulin-dependent protein kinase II contributes to activity-dependent filopodia growth and spine formation. J Neurosci 23:10645-10649.

Kammermeier PJ (2006) Surface clustering of metabotropic glutamate receptor 1 induced by long Homer proteins. BMC Neurosci 7:1.

Kang H, Schuman EM (1996) A requirement for local protein synthesis in neurotrophin-induced hippocampal synaptic plasticity. Science 273:1402-1406.

Khandjian EW, Huot ME, Tremblay S, Davidovic L, Mazroui R, Bardoni B (2004) Biochemical evidence for the association of Fragile X mental retardation protein with brain polyribosomal ribonucleoparticles. Proc Natl Acad Sci USA 101:13357-13362.

Kim E, Sheng M (2004) PDZ domain proteins of synapses. Nat Rev Neurosci 5:771-781.

Kleim JA, Bruneau R, Calder K, Pocock D, VandenBerg PM, MacDonald E, Monfils MH, Sutherland RJ, Nader K (2003) Functional organization of adult motor cortex is dependent upon continued protein synthesis. Neuron 40:167-176.

Kobayashi K, Kuroda S, Fukata M, Nakamura T, Nagase T, Nomura N, Matsuura Y, Yoshida-Kubomura N, Iwamatsu A, Kaibuchi K (1998)
p140Sra-1 (specifically Rac1-associated protein) is a novel specific target for Racl small GTPase. J Biol Chem 273:291-295.

Laggerbauer B, Ostareck D, Keidel EM, Ostareck-Lederer A, Fischer U (2001) Evidence that Fragile X mental retardation protein is a negative regulator of translation. Hum Mol Genet 10:329-338.

Lee CC, Huang CC, Wu MY, Hsu KS (2005) Insulin stimulates postsynaptic density-95 protein translation via the phosphoinositide 3-kinase-Aktmammalian target of rapamycin signaling pathway. J Biol Chem 280:18543-18550.

Li Z, Zhang Y, Ku L, Wilkinson KD, Warren ST, Feng Y (2001) The Fragile $\mathrm{X}$ mental retardation protein inhibits translation via interacting with mRNA. Nucleic Acids Res 29:2276-2283.

Lu R, Wang H, Liang Z, Ku L, O’Donnell WT, Li W, Warren ST, Feng Y (2004) The Fragile X protein controls microtubule-associated protein 1B translation and microtubule stability in brain neuron development. Proc Natl Acad Sci USA 101:15201-15206.

Majewska A, Sur M (2003) Motility of dendritic spines in visual cortex in vivo: changes during the critical period and effects of visual deprivation. Proc Natl Acad Sci USA 100:16024-16029.

Markham JA, Beckel-Mitchener AC, Estrada CM, Greenough WT (2006) Corticosterone response to acute stress in a mouse model of Fragile $\mathrm{X}$ syndrome. Psychoneuroendocrinology 31:781-785.

Martone ME, Pollock JA, Jones YZ, Ellisman MH (1996) Ultrastructural localization of dendritic messenger RNA in adult rat hippocampus. J Neurosci 16:7437-7446.

Merrill MA, Chen Y, Strack S, Hell JW (2005) Activity-driven postsynaptic translocation of CaMKII. Trends Pharmacol Sci 26:645-653.

Miller S, Yasuda M, Coats JK, Jones Y, Martone ME, Mayford M (2002) Disruption of dendritic translation of CaMKIIalpha impairs stabilization of synaptic plasticity and memory consolidation. Neuron 36:507-519.

Miyashiro KY, Beckel-Mitchener A, Purk TP, Becker KG, Barret T, Liu L, Carbonetto S, Weiler IJ, Greenough WT, Eberwine J (2003) RNA cargoes associating with FMRP reveal deficits in cellular functioning in Fmr1 null mice. Neuron 37:417-431.

Ostroff LE, Fiala JC, Allwardt B, Harris KM (2002) Polyribosomes redistribute from dendritic shafts into spines with enlarged synapses during LTP in developing rat hippocampal slices. Neuron 35:535-545.

Otmakhov N, Tao-Cheng JH, Carpenter S, Asrican B, Dosemeci A, Reese TS, Lisman J (2004) Persistent accumulation of calcium/calmodulindependent protein kinase II in dendritic spines after induction of NMDA receptor-dependent chemical long-term potentiation. J Neurosci 24:9324-9331.

Ouyang Y, Wong M, Capani F, Rensing N, Lee CS, Liu Q, Neusch C, Martone ME, Wu JY, Yamada K, Ellisman MH, Choi DW (2005) Transient decrease in F-actin may be necessary for translocation of proteins into dendritic spines. Eur J Neurosci 22:2995-3005.

Penzes P, Johnson RC, Sattler R, Zhang X, Huganir RL, Kambampati V, Mains RE, Eipper BA (2001) The neuronal Rho-GEF Kalirin-7 interacts with PDZ domain-containing proteins and regulates dendritic morphogenesis. Neuron 29:229-242.

Pfeiffer BE, Huber KM (2006) Current advances in local protein synthesis and synaptic plasticity. J Neurosci 26:7147-7150.

Purpura D (1974) Dendritic spine "dysgenesis" and mental retardation. Science 186:1126-1128.

Robison AJ, Bass MA, Jiao Y, MacMillan LB, Carmody LC, Bartlett RK, Colbran RJ (2005) Multivalent interactions of calcium/calmodulindependent protein kinase II with the postsynaptic density proteins NR2B, densin-180, and alpha-actinin-2. J Biol Chem 280:35329-35336.

Roussignol G, Ango F, Romorini S, Tu JC, Sala C, Worley PF, Bockaert J, Fagni L (2005) Shank expression is sufficient to induce functional dendritic spine synapses in aspiny neurons. J Neurosci 25:3560-3570.

Sala C, Piech V, Wilson NR, Passafaro M, Liu G, Sheng M (2001) Regulation of dendritic spine morphology and synaptic function by Shank and Homer. Neuron 31:115-130.

Schenck A, Bardoni B, Langmann C, Harden N, Mandel JL, Giangrande A (2003) CYFIP/Sra-1 controls neuronal connectivity in Drosophila and links the Racl GTPase pathway to the fragile X protein. Neuron 38:887-898.

Schratt GM, Nigh EA, Chen WG, Hu L, Greenberg ME (2004) BDNF regulates the translation of a select group of mRNAs by a mammalian target of rapamycin-phosphatidylinositol 3-kinase-dependent pathway during neuronal development. J Neurosci 24:7366-7377. 
Schuman EM, Dynes J, Steward O (2006) Synaptic regulation of translation of dendritic mRNAs. J Neurosci 26:7143-7146.

Shiraishi Y, Mizutani A, Bito H, Fujisawa K, Narumiya S, Mikoshiba K, Furuichi T (1999) Cupidin, an isoform of Homer/Vesl, interacts with the actin cytoskeleton and activated rho family small GTPases and is expressed in developing mouse cerebellar granule cells. J Neurosci 19:8389-8400.

Sin WC, Haas K, Ruthazer ES, Cline HT (2002) Dendrite growth increased by visual activity requires NMDA receptor and Rho GTPases. Nature 419:475-480.

Smith WB, Starck SR, Roberts RW, Schuman EM (2005) Dopaminergic stimulation of local protein synthesis enhances surface expression of GluR1 and synaptic transmission in hippocampal neurons. Neuron 45:765-779.

Song B, Yan XB, Zhang GY (2004) PSD-95 promotes CaMKII-catalyzed serine phosphorylation of the synaptic RAS-GTPase activating protein SynGAP after transient brain ischemia in rat hippocampus. Brain Res 1005:44-50.

Steward O, Falk PM (1986) Protein-synthetic machinery at postsynaptic sites during synaptogenesis: a quantitative study of the association between polyribosomes and developing synapses. J Neurosci 6:412-423.

Sung YJ, Conti J, Currie JR, Brown WT, Denman RB (2000) RNAs that interact with the Fragile X syndrome RNA binding protein FMRP. Biochem Biophys Res Commun 275:973-980.

Tada T, Sheng M (2006) Molecular mechanisms of dendritic spine morphogenesis. Curr Opin Neurobiol 16:95-101.

Tashiro A, Yuste R (2004) Regulation of dendritic spine motility and stability by Rac1 and Rho kinase: evidence for two forms of spine motility. Mol Cell Neurosci 26:429-440.

Tiruchinapalli DM, Oleynikov Y, Kelic S, Shenoy SM, Hartley A, Stanton PK, Singer RH, Bassell GJ (2003) Activity-dependent trafficking and dynamic localization of zipcode binding protein 1 and $\beta$-actin mRNA in dendrites and spines of hippocampal neurons. J Neurosci 23:3251-3261.

Todd PK, Mack KJ, Malter JS (2003) The Fragile X mental retardation pro- tein is required for type-I metabotropic glutamate receptor-dependent translation of PSD-95. Proc Natl Acad Sci USA 100:14374-14378.

Vanderklish PW, Edelman GM (2002) Dendritic spines elongate after stimulation of group 1 metabotropic glutamate receptors in cultured hippocampal neurons. Proc Natl Acad Sci USA 99:1639-1644.

van Kesteren RE, Carter C, Dissel HM, van Minnen J, Gouwenberg Y, Syed NI, Spencer GE, Smit AB (2006) Local synthesis of actin-binding protein $\beta$-thymosin regulates neurite outgrowth. J Neurosci 26:152-157.

Vickers CA, Dickson KS, Wyllie DJ (2005) Induction and maintenance of late-phase long-term potentiation in isolated dendrites of rat hippocampal CA1 pyramidal neurones. J Physiol (Lond) 568:803-813.

Weiler IJ (2005) FMRP and the regulation of protein translation near synapses. In: The molecular basis of Fragile X syndrome (Denman RB, Sung YJ, eds), pp 201-215. Kerala, India: Research Signpost.

Weiler IJ, Irwin SA, Klintsova AY, Spencer CM, Brazelton AD, Miyashiro K, Comery TA, Patel B, Eberwine J, Greenough WT (1997) Fragile X mental retardation protein is translated near synapses in response to neurotransmitter activation. Proc Natl Acad Sci USA 94:5395-5400.

Weiler IJ, Spangler CC, Klintsova AY, Grossman AW, Kim SH, BertainaAnglade V, Khaliq H, de Vries FE, Lambers FA, Hatia F, Base CK, Greenough WT (2004) Fragile X mental retardation protein is necessary for neurotransmitter-activated protein translation at synapses. Proc Natl Acad Sci USA 101:17504-17509.

Wells DG (2006) RNA-binding proteins: a lesson in repression. J Neurosci 26:7135-7138.

Zalfa F, Giorgi M, Primerano B, Moro A, Di Penta A, Reis S, Oostra B, Bagni C (2003) The Fragile X syndrome protein FMRP associates with BC1 RNA and regulates the translation of specific mRNAs at synapses. Cell 112:317-327.

Zhou Q, Homma KJ, Poo MM (2004) Shrinkage of dendritic spines associated with long-term depression of hippocampal synapses. Neuron 44:749-757.

Zuo Y, Yang G, Kwon E, Gan WB (2005) Long-term sensory deprivation prevents dendritic spine loss in primary somatosensory cortex. Nature 436:261-265. 